\title{
Ophidian envenomation in Morocco: Analysis of specific hospitalization records (2012-2015)
}

\author{
Faiçal El Hattimy ${ }^{1}$, Chafiq Fouad $^{2}$, Hermann-Désiré Lallié ${ }^{3}$, Abdelrhani Mokhtari ${ }^{1}$, Abdelmajid Soulaymani, $^{1}$ \\ and Rachida Soulaymani ${ }^{2}$ \\ ${ }^{I}$ Ibn Tofail University, Faculty of Science, Laboratory of Biology and Health, BP 242 Kenitra, Morocco. \\ ${ }^{2}$ Centre Anti Poison et de Pharmacovigilance du Maroc, Rabat, Maroc \\ ${ }^{3}$ Péléforo GON COULIBALY University, Training and Research Unit of Biological Sciences, Department of Biochemistry \\ and Genetics, BP 1328 Korhogo, Côte d'Ivoire.
}

\begin{abstract}
Snakebites are a real public health problem in Morocco, from the point of view of incidence and mortality. Inorder to contribute to the reduction of the resulting morbidity and mortality, the present work aims to describe the epidemiological profile of cases of Snakebites and to follow the spatio-temporal trends of the health indicators studied (incidence, fatality and mortality). The methodology adopted consists of a retrospective analysis of the cases collected from the Anti Poison and Pharmacovigilance Center of Morocco from specific hospitalization records. Between 2012 and 2015, the MPCC gathered 224 cases. The mean age was $26.9 \pm 18.9$ years with a sex ratio $(\mathrm{M} / \mathrm{F})$ of 1.4. Most of the bites occurred during hot seasons $(84 \%)$ and in rural areas $(95 \%)$. The time to hospitalization exceeded 24 hours in $7 \%$ of cases. Clinically, compartment syndrome was observed in 17 patients, renal failure in 13 patients and shock in 13 patients. The distribution according to clinical gradation was almost uniform. From a therapeutic standpoint, in addition to the antivenom, two types of treatment were the most recommended: symptomatic treatment based on the administration of analgesics $(n=168)$ and on the administration of an antitetanus serum $(n=99)$, and treatment involving transfusion $(n=58)$. Analysis of all of these files enabled us to detect parameters having a direct impact on morbidity and mortality following a bite and ophidian envenomation, on which the competent authorities should focus in order to thwart this scourge and its complications.
\end{abstract}

Keywords: Snakebites; Epidemiological profile; Morbi-mortality; Morocco

\section{INTRODUCTION}

Snake bite envenomation remains a serious health risk and threat throughout the world, including morocco, recording an annual incidence of about 0.5 bites per 100,000 inhabitants a fatality rate of $4 \%$ [1].

Among 3000 snake species reported worldwide, around $30 \%$ are venomous snakes [2]. In Morocco, the ophidian fauna of the country consists of twenty-eight species, eight of which are poisonous represented by two families, Elapidae (with one species) and Viperidae (with seven species) [3].

To deal with that, snake bites has been integrated into the national envenomation control strategy since May 20, 2013[4]. The aim of this study was to describe the epidemiological characteristics of snake bites after the national envenomation strategy, Morocco over a four years period from 2012 through 2015

\section{PATIENTS ET METHODS}

\subsection{Structure}

The Anti Poison and Pharmacovigilance Center of Morocco (MPCC) is the public utility institution mandated by the Ministry of Health, responsible for the management of poisoning at the individual and collective level in Morocco. It ensures a vigilance and health alert function, to reduce mortality, morbidity and health expenses related to poisoning and envenomation

\subsection{Patients}

Cases collected at the Poison Control and Pharmacovigilance Center of Morocco (MAPPC), Through 2012 to 2015

\subsection{Methods}

This study is a descriptive retrospective analysis of all reported cases collected at the Poison Control and Pharmacovigilance Center of Morocco (MAPPC), Through 2012 to 2015 from hospitalization records specific to snakebites. Frequencies were calculated to describe the characteristics that were studied.

\section{RESULTS}

Since 2012, 224 cases have been collected at the Poison Control and Pharmacovigilance Center of 
Morocco. Table 1 follows provides us with an epidemiological profile of all these patients.

Table 1: Epidemiological characteristics of snakebites

\begin{tabular}{|c|c|c|}
\hline Characteristics & Total & $\%$ \\
\hline \multicolumn{3}{|l|}{ Sex } \\
\hline Female & 92 & 41 \\
\hline Male & 132 & 59 \\
\hline \multicolumn{3}{|l|}{ Age } \\
\hline Child (less than or equal to 15 ) & 76 & 35 \\
\hline Adult (greater than 15) & 141 & 65 \\
\hline \multicolumn{3}{|l|}{ Location } \\
\hline Rural & 188 & 95 \\
\hline Urban & 10 & 5 \\
\hline \multicolumn{3}{|l|}{ Seat of bite } \\
\hline upper limb & 92 & 54 \\
\hline lower limb & 78 & 46 \\
\hline \multicolumn{3}{|l|}{ Contraindicated gesture } \\
\hline Applying the tourniquet & 56 & 62 \\
\hline suck on the wound & 13 & 14 \\
\hline Incision & 15 & 17 \\
\hline traditional therapies & 6 & 7 \\
\hline \multicolumn{3}{|l|}{ Season } \\
\hline Autumn & 25 & 11 \\
\hline Winter & 11 & 5 \\
\hline Spring & 75 & 34 \\
\hline Summer & 112 & 50 \\
\hline \multicolumn{3}{|l|}{ Deadline } \\
\hline$\geq 24$ hours & 8 & 7 \\
\hline$<24$ hours & 113 & 93 \\
\hline
\end{tabular}

The majority of cases were men (59\%), the average age of these patients was $26.9 \pm 18.9$ years. They live mostly in rural location $(95 \%)$, half of recorded bites occurs in summer, mostly with a hospital stay of less than 24 hours (93\%),

The site of the bites was determined in 170 cases. The upper limb was the most affected (92 cases; $54 \%$ ), especially in the right hand (38 cases). The other cases were bitten on the lower limb, namely the left foot.

Prior to admission, 76 victims used traditional practices more than once, in $10.5 \%$ of cases, and most patients used tourniquets (56 cases), incisions (15 cases) or sucking (13 cases).

The initial grade was mostly grade 0 (29\% of cases) and, grade 1 (30\% of cases), the white bite represented $14 \%$ of cases. Patients' condition was worsened (upgraded to a higher grade) 25 times, from grade 1 to grade 3 in 6 patients and from grade 2 to grade 3 in 5 patients, while the condition improved in 10 patients.

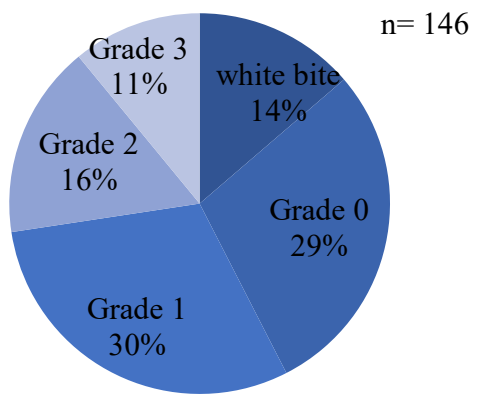

Figure 1: Distribution of the gradation of snakebites

In this study, 186 victims were symptomatic cases, or $83 \%$ of the total cases studied. Most of the victims (121 cases) presented with pain. Among these victims, 125 patients presented with edema (local, regional or extensive). The table 2 shows the frequency of symptoms

Table 2: Distribution of patients according to clinical signs

\begin{tabular}{|c|c|c|c|c|}
\hline & Symptoms & & & $\%$ \\
\hline & & Moderate & 67 & 9,3 \\
\hline & Pain & Important & 54 & 7,5 \\
\hline & & Local & 42 & 5,8 \\
\hline & & Régional & 54 & 7,5 \\
\hline & Edemas & Extensive & 29 & 4,0 \\
\hline & Bruises & & 43 & 6,0 \\
\hline & phlyctenules & & 40 & 5,5 \\
\hline & necrosis & & 19 & 2,6 \\
\hline & Cyanosis & & 6 & 0,8 \\
\hline & Paresthesia & & 2 & \\
\hline & & & & 0,3 \\
\hline & Vomiting & & 15 & 2,1 \\
\hline Digestive & Nausea & & 7 & 1,0 \\
\hline & Abdominal pain & & 1 & 0,1 \\
\hline Cardiac & Arterial hypotension & & 16 & 2,2 \\
\hline
\end{tabular}

Two types of treatment were used after a snakebite, symptomatic treatment based on the administration of analgesics $(n=168)$, on the administration of an antitetanus serum in 99 patients, and on antibiotic prophylaxis $(n=107)$. The second type of treatment was linked to the complications observed in the patients, it was mainly based on transfusion in 58 patients (fresh frozen plasma, red blood cells, platelet pellets), the management of cardiovascular distress $(n=22)$, and a fasciotomy dischargein 17 patients. antivenom was administered to 56 patients, with a mean administration time of $19.7 \mathrm{~h}$ $\pm 20.7 \mathrm{~h}$. The average number of ampoules administered was $2 \pm 0.9$ ampoules per person.

Patient outcomes were mostly favorable in 141 cases, sequelae were noted in 15 patients, and 10 people died. 


\section{DISCUSSION}

In many regions of the world, snake bites are an important public health problem, as has been shown in many studies, bites occur especially in rural areas, and most victims were adults [5]. According to the results, most incidents occurred during the spring and summer months, when snakes are more active $[6,7]$. The warm period of the year coincides with the harvesting period: people are more active in the fields and therefore are more frequently exposed to snakes, which explains the high frequency of bites and envenomations outside the home. $[8,9]$

The specific hospital records included new parameters specific to the bite; the site of the bite, contraindicated gesture, detailed symptomatology (biological assessment and complications), clinical gradation and recommended treatment.

According to the results of the statistical analysis, the snake bites were localized in the lower limbs and upper limbs of the victims, while in intertropical Africa the site of the bite is most often in the foot or leg $[10,11]$.

For customary and economic reasons, several victims had committed at least one prohibited act (sussions, tourniquet, incision) following a snake bite. These behaviors delay medical treatment and jeopardize the functional prognosis of the bitten limb as well as the patient's vital prognosis [12, 13].The tourniquet was the most performed. This gesture is however to be avoided; it promotes limb ischemia and retention of the poison in the tissue [14].

There is no cobraic syndrome in our study, consisting mainly of paralysis of the respiratory muscles and striated muscles, has been described. This is predictable given its threatened Mediterranean population [15].

The distribution of bites according to clinical gradation was almost uniform, while another study showed that the incidence of grades 2 and 3 was significant [15].

Antivenom immunotherapy remains the only septic treatment for severe ophidic envenomation [15]. In our study, this treatment was recommended for certain cases

For the clinical course, fourteen cases had retained sequelae. According to the literature, envenomations are associated with mainly locomotor sequelae, and are responsible for around 400,000 amputations each year [17]. Death was reported in ten patients $(4.5 \%)$, six of them had presented a state of shock, which, according to
Berdai and his collaborators, can be refractory to the vasopressor drugs or hemorrhagic (hematemesis, hematuria, bleeding at the level bite site) [17].

\section{CONCLUSION}

Analysis of all of these files enabled us to detect parameters having a direct impact on morbidity and mortality following a bite and ophidian envenomation, on which the competent authorities should focus in order to thwart this scourge and its complications.

\section{References}

[1] F. El Hattimy, F. Chafiq, H. Hami, A. Mokhtari, A. Soulaymani, R. Soulaymani Bencheikh,.Geographical distribution of health indicators related to snake bites and envenomation in Morocco between 1999 and 2013. Epidemiol Health 2018;40:e2018024.

[2] M. K.Al-Sadoon,Mohammed F. Albeshr, B. Ahamad Paray, A. Al-Mfarij. Envenomation and the bite rate by venomous snakes in the kingdom of Saudi Arabia over the period (2015-2018). Saudi Journal of Biological Sciences Volume 28, Issue 1, January 2021, Pages 582-586

[3] M. FEKHAOUI, Amphibiens et Reptiles $d u$ Maroc : étude nationale sur la biodiversité. Observatoire National de l'Environnement, Ministère de l'Environnement, 1998, 114.

[4] F.Chafiq, H. Chaoui, N. Rhalem, I .Semlali, R . El Oufir, R. Aghandous. National strategy of snake envenomations management. Toxicol Maroc 2015;24:3-7.

[5] F. Chafiq, F. El Hattimy, N. Rhalem, JP. Chippaux, A. Soulaymani, A. Mokhtari,. Snakebites notified to the poison control center of Morocco between 2009 and 2013. J Venom Anim Toxins Incl Trop Dis 2016;22:8.

[6] G. Ozay, M. Bosnak M, A. Ece, M .Davutoglu, B. Dikici, F. Gurkan,. Clinical characteristics of children with snakebite poisoning and management of complications in the pediatric intensive care unit. Pediatr Int 2005;47:669675.

[7] P. Petite J. Viper bites: treat or ignore? Review of a series of 99 patients bitten by Vipera aspis in an alpine Swiss area. Swiss Med Wkly 2005;135:618-625.

[8] N. Sharma, S. Chauhan, S. Faruqi, P. Bhat, S. Varma, Snake envenomation in a north Indian hospital. Emerg Med J 2005;22:118-120.

[9] R. Dehghani, B. Fathi, MP. Shahi, M. Jazayeri Ten years of snakebites in Iran. Toxicon 2014;90:291-298. 
[10]JP. CHIPPAUX, Les morsures de serpents en Afrique intertropicale. Cahiers Santé $1992 ; 2$ : 221-34.

[11]B. DRAMÉ, N. DIANI, M. TOGO, M. MAÏGA, D. DIALlO, A. TRAORE. Les accidents d'envenimation par morsure de serpent dans le service des urgences chirurgicales de l'hôpital Gabriel-Touré, Bamako, Mali (1998-1999). Bull Soc Pathol Exot, 2005, 98, 4, 287-289.

[12]N.R. KOFFI, E.K. KOUAME, Y.P. YAPO Morsure de vipère des organes génitaux chez un enfant. Arch Pediatr 2015;22: 865-7.

[13] JP. BELLEFLEUR, P. LE DANTEC, Prise en charge hospitalière des morsures de serpent en Afrique. Bull Soc Pathol Exot 2005; 98:273-6.

[14]F. ESSI AIT, M.A. BENHIMA, I. ABKARI, Y. NAJEB, M. LATIFI, M. KHALLOUKI, M.A. SAMKAOUI, L'amputation des doigts par morsure de serpent : à propos de trois cas Chir Main, 32 (2013), pp. 92-95

[15] N. COX, J. CHANSON, S. STUART, Statut de conservation et répartition géographique des reptiles et amphibiens $d u$ bassin méditerranéen, Programme des espèces de l'UICN 2007.

[16] G. MION, S. LARRÉCHÉ, M. GOYFFON Aspects cliniques et thérapeutiques des envenimations graves. Ganges: Urgences PratiquesPublications, 2010. p. 116-123.

[17]JP. CHIPPAUX, Snake-bites: appraisal of the global situation. Bull World Healtb Organ $1998 ; 75: 515-24$

[18] MA. BERDAI, S. LABIB, M. HARANDOU, L'envenimation ophidienne pédiatrique au centre hospitalier universitaire de Fès (Maroc) 2013. Medicine et Santé Tropicales ; $23: 427$ 432 